EIS $12 / 2018$

Economic Integration and Corruption - EU Enlargement in Western Balkans

Submitted $04 / 2018$

Accepted for publication $10 / 2018$

\title{
Economic Integration
} and Corruption -
EU Enlargement in
Western Balkans

\section{Hannu Laurila}

University of Tampere erossef http://dx.doi.org/10.5755/j01.eis.0.12.21524

The paper examines possible EU enlargement in Western Balkans from the point of view corruption. Transparency International warns from the risks of acceleration and spreading of corruption in economic integration between states with different levels of integrity, and draws ambitious guidelines for optimal anticorruption policy. The paper aims for policy advices concerning proper anticorruption policy. The method is, first, to compare the candidate states to the current $28 \mathrm{EU}$ states in terms of corruption and the quality of governance. Second, the paper surveys relevant economic literature on the macroeconomic effects of corruption, which shows that in countries, that are imprinted by both corruption and bad governance, particularly in terms of rule of law and government effectiveness, a straightforward attack on corruption is hopeless, and it may even be economically detrimental. The conclusion is that following the guidelines given by Transparency International is a too winding path to take, and it is almost impossible to set integrity as a precondition for entry. Optimal policy to avoid the contagion of corruption is to focus not on the candidates, but on the existing EU28, and particularly on close neighbors of the candidates. This can be done best by concentrating on international business transactions, namely by strict enforcement of the OECD anticorruption convention. The EU should pressure all member countries to uniform commitment to that project. After the entrance, the rooting out of corruption and the enhancement of formal governance in the new member states can then be carried out in due course.

KEYWORDS: anticorruption convention; contagion of corruption; government effectiveness; rule of law; second-best policy.

The author thanks two anonymous referees of this Journal for their valuable comments.

The purpose of this paper is to assess the EU enlargement towards Western Balkans from the viewpoint of corruption. Transparency International (2015) has highlighted the risk that economic integration and opening borders for trade may make corruption accelerate and spread from more corrupt countries to less corrupt ones. This fear is quite evident with the Western Balkan candidate countries, since corruption is a persistent problem within them and concerns many of their close neighbors and trade partners, too. Transparency International provides quite ambitious guidelines as conditions for integration that would necessitate a deep reorientation within the whole EU.

The research task is to show that the candidate countries suffer from bad governance, including corruption, and that the suggested linkage to the EU single market may expose their trading 
partners, especially in the close neighborhood, to contagion of corruption. Descriptive method is used to present the situation within the candidate countries with respect to that in the existing EU countries, and to pinpoint the profound distortions in formal governance not only in the candidate countries but also in some of the most relevant trading partners. Moreover, the issue of corruption is tackled also from the point of view its macroeconomic effects. The final aim of the paper is to analyze, whether the first-best policy suggested by Transparency International is an appropriate way to take, or would it be better to take a second-best approach. The argument is that the profound distortions in the candidate countries and in their natural trade partners make the setting a second-best environment, where a more realistic integration policy in terms of combating corruption is appropriate.

The paper proceeds as follows. First, the candidate countries Albania, Macedonia, Montenegro and Serbia, and potential candidates Bosnia and Herzegovina, and Kosovo are set in comparison with the existing EU countries with reference to trade connections, corruption, and the quality of governance. Second, the literature on the macroeconomic effects of corruption is briefly surveyed. The third section assesses the optimal stance towards the issue of corruption in the enlargement process. The concluding section states that, instead of focusing on rapid defeats against corruption in the candidate countries, the mother EU should rather concentrate on its own house-cleaning, and especially on the integrity of its business sector when it penetrates into the new markets. A key policy instrument is strict and exhaustive enforcement of the OECD anticorruption convention (1997).

The EU enlargement process has lately been oriented to Western Balkans. Currently, Croatia is the only EU member state in that region, and the rest of the Balkan states are either official candidate countries, including Albania, Macedonia, Montenegro, and Serbia, or potential candidate countries, including Bosnia and Herzegovina, and Kosovo.

This time, the enlargement process is somewhat different than before (European Parliament Think Tank, 2016). There are two main reasons for that. First, the EU itself is in a flux. This is partly reflected by the five-year halt to enlargement since 2014, and the current refugee crisis has even increased the menaces. The Brexit in June 2016, growing threat of terrorism, and the rise of radical right-wing parties, populism, and nationalism in many countries pose notable reluctance towards opening borders. Second, the Western Balkan countries present a particularly complex case. Those countries are still under transition towards market based democracy, and their economic development has not accelerated notably. Adjacent to that, the legacy of severe armed conflicts and bilateral disputes is still haunting. The region is also in the heart of the refugee transit.

Still, the EU has recently confirmed that the inclusion of the Western Balkans remains on the agenda and is a matter of mutual interest. Due to the complexity of the case of the Western Balkan countries, a scrutinized stabilization and association process is implemented to carry out their gradual integration into the EU. "The bar for accession has been set higher" for the candidate countries because of the increased focus on conditionality, reshuffled priorities, and rule of law as a major area of concern. Pre-accession monitoring is emphasized instead of post-accession monitoring, which has proven inefficient for example in the cases of Bulgaria and Romania.

Another highlight is the increased focus on regional cooperation. The idea is that, while enlargement is on hold, cooperation could give fresh impetus to the region's economic performance, reconcile societies, and prepare them for the eventual EU entry. Yet, besides problems with rule 
of law, a key element in the complexity of the case of Western Balkan countries is the existence of pervasive corruption, intertwined with deficient formal governance. In such circumstances, facilities for healthy regional cooperation that would prepare the area for EU entry are poor, indeed. Thus, the focus must be also on government effectiveness.

A somewhat similar situation emerged in Southeast Asia, where the ASEAN Economic Community was established in 2015. With respect to that initiative, Transparency International (2015) warned that economic integration is risky between countries that differ in terms of corruption. Increasing cross-border trade, investments, and migration of people and capital create new opportunities, or even necessities, for illicit transfers and corrupt actions. Therefore, economic integration may not only accelerate corruption in the newcomers but also make it spread to the initial member countries. Moreover, since corruption distributes the economic benefits unequally, there is a notable danger of the accumulation of social unrest.

Transparency International's suggestion for solving the issue of corruption in Southeast Asia is to build an "ASEAN Integrity Community". That should include achieving effective anticorruption policies, legislation and strategies; strong and independent anticorruption institutions; intergovernmental anti-corruption cooperation; and meaningful engagement with civil society and the business sector. So far, these ambitious initiatives don't seem to have actualized, and corruption still strikes at the roots of the area's development (Checchi, 2017).

The average state of integrity within the present EU is fairly good, far better that in the candidate countries. Yet, there are also some problematic EU economies, particularly in the close neighborhood of the candidate countries. Thus, there is a noteworthy risk of cross-border contagion of corruption, and the warning by Transparency International must be taken seriously when assessing EU enlargement in Western Balkans. Since the economic gains generated by the single market is one of the cornerstones of the enlargement process, the assessment needs also consideration of the economic effects of corruption.

There is no doubt that corruption causes microeconomic damages by erecting biased incentives and distorting the allocation of resources. However, the question about its macroeconomic effects is more obscure. The mainstream view still is that corruption is pernicious on economic performance, but there is also some evidence about positive macroeconomic effects in countries that suffer from flawed governance. The evidence is especially noteworthy, when the quality of governance is monitored in terms of rule of law, and government effectiveness. In such surroundings, corruption may have lucrative economic effects, if corruption initially acts rather as a complement than a substitute to formal governance. If so, rapid rooting out of corruption in terms of pre-accession monitoring would be very hard.

The warning of Transparency International (2015) that corruption endangers economic integration is broadly based on the argument that the increase of trade within the widened single market makes corrupt behavior accelerate and spread across the partner countries thus causing economic inefficiency and social problems. Therefore, the biggest intra-EU traders, and also the close neighbors of the candidate countries are the most probable victims of contagion. Table 1 reports the share-out of intra-EU trade between the current 28 member states.

Table 1 shows that the power of trade in Europe is highly concentrated. In 2015, the three biggest traders, Germany, France, and UK cover about $43 \%$ of the intra-EU trade, and the seven biggest traders, Germany, France, UK, Italy, Belgium, Netherlands, and Spain cover about $70 \%$ of the trade. Of these, Germany, UK, and Spain are on a rising trend, while the others decline in their share of mutual trade within the EU. 


\begin{tabular}{|c|c|c|c|c|}
\hline Country & 2012 & 2013 & 2014 & 2015 \\
\hline Austria & 3.8 & 3.8 & 3.7 & 3.6 \\
\hline Belgium & 8.3 & 8.2 & 7.8 & 7.1 \\
\hline Bulgaria & 0.5 & 0.6 & 0.6 & 0.6 \\
\hline Croatia & 0.4 & 0.4 & 0.5 & 0.5 \\
\hline Czech Republic & 3.0 & 3.0 & 3.2 & 3.3 \\
\hline Cyprus & 0.1 & 0.1 & 0.1 & 0.1 \\
\hline Denmark & 1.8 & 1.8 & 1.8 & 1.8 \\
\hline Estonia & 0.4 & 0.4 & 0.4 & 0.4 \\
\hline Finland & 1.4 & 1.4 & 1.4 & 1.3 \\
\hline France & 12.7 & 12.6 & 12.1 & 11.8 \\
\hline Germany & 20.6 & 20.8 & 20.8 & 20.9 \\
\hline Greece & 0.8 & 0.8 & 0.8 & 0.8 \\
\hline Hungary & 1.9 & 2.0 & 2.1 & 2.1 \\
\hline Ireland & 1.2 & 1.3 & 1.4 & 1.5 \\
\hline Italy & 7.3 & 7.2 & 7.1 & 7.2 \\
\hline Latvia & 0.4 & 0.4 & 0.4 & 0.3 \\
\hline Lithuania & 0.5 & 0.6 & 0.6 & 0.6 \\
\hline Luxembourg & 0.6 & 0.6 & 0.6 & 0.5 \\
\hline Malta & 0.1 & 0.1 & 0.1 & 0.1 \\
\hline Netherlands & 7.5 & 7.4 & 7.1 & 7.0 \\
\hline Poland & 3.8 & 3.9 & 4.1 & 4.1 \\
\hline Portugal & 1.5 & 1.5 & 1.5 & 1.5 \\
\hline Romania & 1.5 & 1.5 & 1.5 & 1.6 \\
\hline Slovakia & 1.6 & 1.7 & 1.6 & 1.8 \\
\hline Slovenia & 0.6 & 0.6 & 0.6 & 0.6 \\
\hline Spain & 5.1 & 5.1 & 5.4 & 5.7 \\
\hline Sweden & 3.1 & 3.0 & 2.9 & 2.9 \\
\hline United Kingdom & 9.3 & 9.3 & 9.6 & 10.2 \\
\hline EU28 & 100 & 100 & 100 & 100 \\
\hline
\end{tabular}

Table 1

Intra-EU28 trade in 2012 2015 , \% of the monetary value of total product

Source: The data from http://ec.europa.eu/eurostat/web/international-trade-in-goods/statistics-illustrated.

A reasonable assumption is that the enlargement of the single market erects new trade connections particularly between close neighbors. The EU neighbors that have common borders with the candidate countries are Bulgaria, Croatia, Greece, Hungary, and Romania. Of these, Hungary, 
and Romania report relatively high activity in trade. Italy can also be regarded a neighbor, because it has a close connection to Western Balkans over the Adriatic Sea. As a notable EU trader, Italy requires special attention in the analysis.

Transparency International (2016) defines corruption as "the abuse of entrusted power for private gain". The concept "grand corruption" refers to misconducts at the top level of government, arising from the leaders' capability to benefit at the expense of the public good, and leading to serious distortions in sector policies and the general functioning of the state. "Petty corruption" refers to abuse of entrusted power by civil servants in their everyday interactions with the service users of hospitals, schools, police departments and other agencies. "Political corruption" means abusive manipulation of the mechanism of public resource allocation by political decision makers, who aim only to sustain their own power, status and wealth.

Transparency International monitors the worldwide extent of corruption by the Corruption Perceptions Index (CPI), and provides comparative time-series of it country by country. The $\mathrm{CPI}$ aggregates data from different sources that provide perceptions of business people and country experts about the level of corruption in the public sector, calculated as the average of the scores from at least three sources. The scale of the index goes from 0 (utmost corruption) to 100 (full integrity). The scores are rounded to whole numbers. The CPI scores in 2015 for the current 28 EU states can be found from the Appendix.

Table 2 below presents the variation of the CPI scores between 2012-2015 for official and potential candidate countries, close EU neighbors (including Italy), and reference EU economies. The last category represents the socio-economic figureheads of the EU. Of these, Germany, France, UK, Belgium, Netherlands, and Spain represent the biggest intra-EU traders (ref. Table 1 and note that, while Italy is excluded from this group, United Kingdom is included in spite of the Brexit decision). Denmark, Finland, and Sweden are included because they constitute not only the top three CPI score countries in the EU but also the core of the Nordic welfare state model.

Table 2 shows that the CPI values of both the official and potential candidate countries have remained far below 50 over 2012-2015, which means that they are regarded as highly corrupted countries by Transparency International. During the time-span, none of the countries shows undisputed improvement in that respect. In 2015, the average CPI score of the official and potential candidates is 38,8 , while the respective figures read 75,7 for the big traders, and 90 for the Nordic welfare sates. The average $\mathrm{CPI}$ for the current EU member states is 65,4 (see the Appendix). Compared to those figures, the average $\mathrm{CPI}$ scores of the candidate countries are markedly low.

The situation is quite the same among the close neighbors. Bulgaria, Greece and Romania are highly corrupt countries, and the bad scores of Italy are noteworthy because of its vivid trade. The average CPI score for the neighbors is 46,5 in 2015, and only Croatia and Hungary barely avoid being labeled as highly corrupt. Croatia shows a slightly rising trend, while Hungary seems to follow a more dismal pattern. However, since the CPI scores, like all perceptions-based measures, are in fact incomparable over time, no definite conclusions can be made about the evolution of corruption in any of the countries listed in Table 2.

The quality of governance is monitored by World Bank's Worldwide Governance Indicators (WGI). The WGI are aggregated from a big amount of underlying variables from a wide variety of data sources, reflecting the views of survey respondents, and public and private experts worldwide. The numerical scale of the WGI goes from -2.5 (minimum quality) to 2.5 (maximum quality). Of course, the measurement of the quality of governance based on any kind of data is inherently difficult, but, 


\begin{tabular}{|c|c|c|c|c|}
\hline Country & 2012 & 2013 & 2014 & 2015 \\
\hline \multicolumn{5}{|l|}{ Official candidates: } \\
\hline Albania & 33 & 31 & 33 & 36 \\
\hline Macedonia & 43 & 44 & 45 & 42 \\
\hline Montenegro & 41 & 44 & 42 & 44 \\
\hline Serbia & 39 & 42 & 41 & 40 \\
\hline \multicolumn{5}{|l|}{ Potential candidates: } \\
\hline Bosnia and Herzegovina & 42 & 42 & 39 & 38 \\
\hline Kosovo & 34 & 33 & 33 & 33 \\
\hline \multicolumn{5}{|l|}{ Close neighbors: } \\
\hline Bulgaria & 41 & 41 & 43 & 41 \\
\hline Croatia & 46 & 48 & 48 & 51 \\
\hline Greece & 36 & 40 & 43 & 46 \\
\hline Hungary & 55 & 54 & 54 & 51 \\
\hline Italy & 42 & 43 & 43 & 44 \\
\hline Romania & 44 & 43 & 43 & 46 \\
\hline \multicolumn{5}{|l|}{ Reference economies: } \\
\hline Belgium & 75 & 75 & 76 & 77 \\
\hline Denmark & 90 & 91 & 92 & 91 \\
\hline Finland & 90 & 89 & 89 & 90 \\
\hline France & 71 & 71 & 69 & 70 \\
\hline Germany & 79 & 78 & 79 & 81 \\
\hline Netherlands & 84 & 83 & 83 & 87 \\
\hline Spain & 60 & 59 & 60 & 58 \\
\hline Sweden & 88 & 89 & 87 & 89 \\
\hline United Kingdom & 74 & 76 & 78 & 81 \\
\hline
\end{tabular}

Table 2

The CPI scores of the candidate countries and select EU countries in 2012-2015

Source: The data from http://www.transparency.org/cpi2015\#results-table.

in any case, the WGI permits meaningful cross-country comparisons (Kauffman, Kraay \& Mastruzzi, 2010).

From the variety of the WGI indicators the most relevant ones for this study are Government Effectiveness (denoted GE), and Rule of Law (denoted RL). GE "reflects perceptions of the quality of public services, the quality of the civil service and the degree of its independence from political pressures, the quality if policy formulation and implementation, and the credibility of the government's commitment to such policies". RL "reflects perceptions of the extent to which agents have confidence in and abide by the rules of society, and in particular the quality of contract enforcement, property rights, the police, and the courts, as well as the likelihood of crime and violence". Thus, GE and RL monitor the issues from both sides: from the viewpoint of the formal governance at all levels, and from the viewpoint of the public's adaptability to the official structures.

Table 3 below collects the $G E$ and $R L$ indicator values over 2012-2015 for the same sets of countries as Table 2. The GE and $R L$ scores of the current $28 \mathrm{EU}$ states in 2015 are reported in the Appendix.

Table 3 shows that the official and potential candidate countries have very poor governance (in spite of the insignificant improvement in the numbers). All and especially the potential candidates 
Table 3

The GE and RL scores in 2012-2015 (GE up and RL below in each cell)

\begin{tabular}{|c|c|c|c|c|}
\hline Country & 2012 & 2013 & 2014 & 2015 \\
\hline \multicolumn{5}{|l|}{ Official candidates: } \\
\hline Albania & $\begin{array}{l}-0.26 \\
-0.57\end{array}$ & $\begin{array}{l}-0.33 \\
-0.57\end{array}$ & $\begin{array}{l}-0.07 \\
-0.37\end{array}$ & $\begin{array}{c}0.03 \\
-0.36\end{array}$ \\
\hline Macedonia & $\begin{array}{l}-0.07 \\
-0.24\end{array}$ & $\begin{array}{l}-0.06 \\
-0.20\end{array}$ & $\begin{array}{c}0.15 \\
-0.03\end{array}$ & $\begin{array}{c}0.13 \\
-0.17\end{array}$ \\
\hline Montenegro & $\begin{array}{c}0.13 \\
-0.01 \\
\end{array}$ & $\begin{array}{l}0.16 \\
0.02\end{array}$ & $\begin{array}{l}0.28 \\
0.07\end{array}$ & $\begin{array}{l}0.16 \\
0.03\end{array}$ \\
\hline Serbia & $\begin{array}{l}-0.11 \\
-0.39 \\
\end{array}$ & $\begin{array}{l}-0.10 \\
-0.34\end{array}$ & $\begin{array}{c}0.09 \\
-0.16\end{array}$ & $\begin{array}{c}0.11 \\
-0.09 \\
\end{array}$ \\
\hline \multicolumn{5}{|l|}{ Potential candidates: } \\
\hline Bosnia and Herzegovina & $\begin{array}{c}0.47 \\
-0.23 \\
\end{array}$ & $\begin{array}{l}-0.45 \\
-0.17 \\
\end{array}$ & $\begin{array}{l}-0.47 \\
-0.20 \\
\end{array}$ & $\begin{array}{l}-0.54 \\
-0.29 \\
\end{array}$ \\
\hline Kosovo & $\begin{array}{l}-0.39 \\
-0.56\end{array}$ & $\begin{array}{l}-0.41 \\
-0.57\end{array}$ & $\begin{array}{l}-0.32 \\
-0.48 \\
\end{array}$ & $\begin{array}{l}-0.42 \\
-0.47\end{array}$ \\
\hline \multicolumn{5}{|l|}{ Close neighbors: } \\
\hline Bulgaria & $\begin{array}{c}0.14 \\
-0.12\end{array}$ & $\begin{array}{c}0.15 \\
-0.14\end{array}$ & $\begin{array}{c}0.09 \\
-0.08\end{array}$ & $\begin{array}{c}0.22 \\
-0.12\end{array}$ \\
\hline Croatia & $\begin{array}{l}0.70 \\
0.21 \\
\end{array}$ & $\begin{array}{l}0.69 \\
0.26\end{array}$ & $\begin{array}{l}0.69 \\
0.31 \\
\end{array}$ & $\begin{array}{l}0.51 \\
0.20 \\
\end{array}$ \\
\hline Greece & $\begin{array}{l}0.31 \\
0.39 \\
\end{array}$ & $\begin{array}{l}0.45 \\
0.44\end{array}$ & $\begin{array}{l}0.40 \\
0.34 \\
\end{array}$ & $\begin{array}{l}0.25 \\
0.24 \\
\end{array}$ \\
\hline Hungary & $\begin{array}{l}0.62 \\
0.60\end{array}$ & $\begin{array}{l}0.64 \\
0.56\end{array}$ & $\begin{array}{l}0.53 \\
0.50\end{array}$ & $\begin{array}{l}0.49 \\
0.40\end{array}$ \\
\hline Italy & $\begin{array}{l}0.41 \\
0.36 \\
\end{array}$ & $\begin{array}{l}0.45 \\
0.36\end{array}$ & $\begin{array}{l}0.38 \\
0.34 \\
\end{array}$ & $\begin{array}{l}0.45 \\
0.25\end{array}$ \\
\hline Romania & $\begin{array}{r}-0.31 \\
0.02 \\
\end{array}$ & $\begin{array}{c}-0.07 \\
0.11\end{array}$ & $\begin{array}{l}0.00 \\
0.15 \\
\end{array}$ & $\begin{array}{c}-0.04 \\
0.15\end{array}$ \\
\hline \multicolumn{5}{|l|}{ Reference economies: } \\
\hline Belgium & $\begin{array}{l}1.59 \\
1.40 \\
\end{array}$ & $\begin{array}{l}1.59 \\
1.40\end{array}$ & $\begin{array}{l}1.40 \\
1.51 \\
\end{array}$ & $\begin{array}{l}1.44 \\
1.42 \\
\end{array}$ \\
\hline Denmark & $\begin{array}{l}1.97 \\
1.85 \\
\end{array}$ & $\begin{array}{l}1.97 \\
1.87\end{array}$ & $\begin{array}{l}1.81 \\
2.09 \\
\end{array}$ & $\begin{array}{l}1.85 \\
2.04 \\
\end{array}$ \\
\hline Finland & $\begin{array}{l}2.21 \\
1.94 \\
\end{array}$ & $\begin{array}{l}2.17 \\
1.93\end{array}$ & $\begin{array}{l}2.02 \\
2.12\end{array}$ & $\begin{array}{l}1.82 \\
2.07\end{array}$ \\
\hline France & $\begin{array}{l}1.33 \\
1.43 \\
\end{array}$ & $\begin{array}{l}1.47 \\
1.40\end{array}$ & $\begin{array}{l}1.40 \\
1.47\end{array}$ & $\begin{array}{l}1.44 \\
1.41\end{array}$ \\
\hline Germany & $\begin{array}{l}1.57 \\
1.64 \\
\end{array}$ & $\begin{array}{l}1.52 \\
1.62\end{array}$ & $\begin{array}{l}1.73 \\
1.85\end{array}$ & $\begin{array}{l}1.74 \\
1.43 \\
\end{array}$ \\
\hline Netherlands & $\begin{array}{l}1.80 \\
1.84 \\
\end{array}$ & $\begin{array}{l}1.77 \\
1.81 \\
\end{array}$ & $\begin{array}{l}1.83 \\
1.98 \\
\end{array}$ & $\begin{array}{l}1.84 \\
1.93 \\
\end{array}$ \\
\hline Spain & $\begin{array}{l}1.12 \\
1.05 \\
\end{array}$ & $\begin{array}{l}1.16 \\
1.01\end{array}$ & $\begin{array}{l}1.15 \\
0.94 \\
\end{array}$ & $\begin{array}{l}1.18 \\
0.90\end{array}$ \\
\hline Sweden & $\begin{array}{l}1.94 \\
1.93 \\
\end{array}$ & $\begin{array}{l}1.89 \\
1.95\end{array}$ & $\begin{array}{l}1.79 \\
1.99\end{array}$ & $\begin{array}{l}1.81 \\
2.04 \\
\end{array}$ \\
\hline United Kingdom & $\begin{array}{l}1.54 \\
1.70\end{array}$ & $\begin{array}{l}1.48 \\
1.68\end{array}$ & $\begin{array}{l}1.62 \\
1.89\end{array}$ & $\begin{array}{l}1.74 \\
1.81\end{array}$ \\
\hline
\end{tabular}

Source: http://databank.worldbank.org/data/reports.aspx?Report_Name=WGI-Table\&ld=ceea4d8 
remain in poor condition in 2015 according to both GE and $R L$. On the average, the candidate countries score -0,09 in $G E$ and $-0,22$ in $R L$ in 2015. The ratings are very low compared to the $E U$ averages 1,13 for $G E$, and 1,12 for $R L$ (see the Appendix).

The situation is only a bit better within the close neighbors. The steadily declining trend of Hungary deserves attention, particularly in the light of the country's recent political decadence, and a dismal fact is that Italy scores badly also in this respect. On the average, the neighbors' scores are 0,33 in $G E$, and 0,19 in $R L$ in 2015,

The reference EU economies portray a totally different and fairly stable picture. The quality of governance at its best in the Nordic welfare states (1,83 in GE and 2,05 in $R L$ on the average in 2015). Note that Netherlands, which obeys a quite similar socio-economic pattern, scores almost equally well. The ratings of Germany and UK stay somewhat lower, but exceed those of France, Belgium, and Spain (see also the Appendix).

By Table 3, the state of the quality of governance in the candidate countries and in their close neighbors compared to the reference countries is pretty much in line with the observations of corruption presented in Table 2. This emphasizes the well known fact that corruption is actually a symptom of more generally flawed governance (Myrdal, 1968).

To sum up the information from Tables1-3, the warning by Transparency International of acceleration and spreading of corruption seems to be noteworthy. The candidate countries are badly corrupt, and so are most of their close EU neighbors. The eventual increase in crossborder trade with neighboring countries opens doors also for corruption to trespass. Moreover, the integrity of large exporting companies of the biggest EU traders may be questioned, too. For example Siemens from Germany was in 2008 caught from vast bribery in corrupt countries (Fisman \& Golden, 2017). Thus, it is quite plausible that the opening of new markets in countries with broadly bad governance can make corruption run riot.

The question about the economic effects of corruption has been widely discussed in the economic literature (for recent summaries, see Ugur, 2014; and Popov, 2015). The mainstream view is that the microeconomic distortions caused by corruption turn to detrimental macroeconomic effects, say, on economic growth, capital accumulation, and employment. This is called the Sand in the Wheels Hypothesis (SWH). For example Mauro (1995) and Mo (2001) support his view. Méon \& Sekkat (2005) finds that corruption hampers growth and investments, and even more so if the quality of governance is bad. This is widely regarded as a seminal confirmation of the strict form of the SWH, albeit the analysis suffers from an error in the main regression formula.

However, there are other visions of corruption, too. A persuasive counterargument to SWH is that the microeconomic distortions caused by otherwise bad governance are more profound than those caused by corruption as such, and that corruption may in effect alleviate the basic distortions thus making the macroeconomic effects of corruption positive. This idea of second-best optimality is called the Grease in the Wheels Hypothesis (GWH) saying that corruption may help economic agents to bypass unnecessary regulations and red tape thus lubricating transactions and enhancing the operative power of the market. For example Leff (1964), and Huntington (1968) are early proponents of this hypothesis, and e.g. Méndez \& Sepulveda (2006) provides more recent empirical support for it.

Kéïta \& Laurila (2017) tackles the controversy by, among other things, remedying the above mentioned regression flaw of Méon \& Sekkat (2005). The paper finds that, while SWH holds in general,

\section{Corruption and economic performance}


there is some support also for GWH, particularly when GE and $R L$ are considered as indicators of the quality of governance, and suggests that corruption in very badly governed countries may foster economic convergence, too. This means that corruption may help less developed economies to catch up with more developed ones (about the conditional convergence hypothesis, see Mankiw \& Weil, 1992), which would act for the economic benefit of the EU enlargement process.

Furthermore, Méon \& Weill (2008) finds that corruption enhances economic efficiency in countries with bad governance, especially when the quality of governance is measured by $G E$ and $R L$. The finding is insightful, because it dives deeper into the origins of the microeconomic distortions caused by deficient governance. Thus, the result constitutes a further pleading for GWH in surroundings, which match the present case of EU enlargement.

The above excerpts from the literature show that there still exists some ambiguity concerning the macroeconomic effects of corruption. However, the key issue seems to be that corruption and the quality of governance are tightly intertwined. Economic distortions can well arise from bureaucrats' self interests, and corruption endogenously leads to bad governance thus exacerbating the distortions (see e.g. Kurer, 1993; and Kauffman \& Wei, 2000). As a matter of fact, major international organizations have widely taken this view of systemic corruption being merely an indicator or broader failures of governance (Fisman \& Golden, 2017).

Prevalent amalgamation of corruption and bad governance usually has a long history and strong socioeconomic roots, which come down to the societal values (i.e. Latency in the AGIL paradigm of Parsons 1970). In this kind of a situation, combating corruption is an extremely difficult and time consuming project, since it necessitates a profound change in the nation's social psychological pattern of behavior (Fisman \& Golden, 2017).

The analysis indicates that the Western Balkan candidate states are countries with broadly poor quality of governance and high corruption rates. It is quite plausible that their prevalent corruption has historically amalgamated with formal governance somewhat complementarily. The fact that such amalgam is hard to melt down must be taken seriously in the stabilization and association process. It would be a mistake to impose tough integrity clauses on the candidate countries as a precondition for entry in the spirit of pre-accession montoring. Moreover, if GWH should happen to hold in these countries, defeating corruption might have negative short-run effects that go beyond the candidate countries. The expected economic gains would wither as the new market opportunities for the bullish entrants shrink thus dampening the expected gains from the enlargement of the single market. The expected boost in the aggregate growth of the EU would also flop due to the slacking catch-up mechanism in the newcomers. All this would shake the economic cornerstone of the integration process.

The first-best solution would be a comprehensive attack on corruption and bad governance both in the candidate countries and the mother EU, as presented by Transparency International (2015) in the context of ASEAN countries. In the present context, the aim would be to establish a "European Integrity Community" that calls "citizens, businesses and civil society alike to fully participate in the reduction of corruption across the region". This would imply the construction of an EU-wide "NorNet welfare state" model with respectable formal governance and unified intolerance of corruption (the label NorNet is because the Netherlands has a quite similar socioeconomic model as the Nordic countries Denmark, Finland, and Sweden, and has nearly as good $C P I, G E$, and $R L$ indicator values). The dismal fact is that carrying out this kind of a first-best plan within a reasonable time-span is merely wishful thinking. 
The second-best optimum is based on the observation of historical amalgamation of corruption and bad governance that is deeply rooted in the socioeconomic mentality. Thus, there is a notable system of informal corrupt governance, which rather complements than substitutes the deficient formal governance. A hasty anticorruption attack might dry this grease, and a wide-eyed European Integrity Community attempt would be too time-consuming. Therefore, something else is needed in order to prevent the spreading of the contagious disease of corruption.

In this second-best world, the acceleration and spreading of corruption can be best avoided by focusing on the on international business transactions from the existing EU countries to the newcomers. This can be easily, rapidly, and effectively done by strict enforcement of the anticorruption convention by OECD (1997). The Convention on Combating Bribery of Foreign Public Officials in International Business Transactions commits all OECD member countries to put in place legislation, which criminalizes bribery of foreign officials by domestic firms. Closely obeyed the convention is a powerful weapon in the battle against corruption.

Still, five of the EU countries have not ratified or acceded to the convention, namely Croatia, Cyprus, Lithuania, Malta, and Romania. Furthermore, the enforcement of the laws has been lax in many of those EU countries that have ratified the convention, even among the states with highest integrity and most reliable governance. The EU should unify the project by urging the non-ratifiers (especially Croatia and Romania) to ratify the convention, and pressing the negligent states, particularly the neighbors of the candidate states (including Italy) to fortify their enforcement. This would also be a loud enough starting shot for the race to the European Integrity Community.

In the stabilization and association process of EU enlargement, there are many important issues to be solved. The issue of apparent corruption in the Western Balkans is only one aspect among others, but it should be tackled with special caution. This is an EU wide concern, because the enlargement of the single market may make corruption spread through trade thus making things even worse. The paper argues that it would be a mistake to rely on pre-accession monitoring of the candidate countries in the hope of internal house-cleaning.

- There are several reasons for this. First, wiping out corruption is not easy. A well-intentioned, externally induced attack against corruption in countries that experience a long history of it may well end to a rout. Second, even if the attack was a success, the result can be a macroeconomic disappointment for the whole EU. Third, defeating corruption is inherently subordinate to the time-consuming consolidation of formal democratic governance of the candidate countries. That is a tedious project, which is on the long-term agenda of the stabilization and association process in any case. And fourth, the twisted motives of big export companies of voluminous EU trades must not be omitted.

- Anti-corruption actions are most effective within countries, in which corruption is not a big issue, and in which the formal democratic governance possesses the requisite arsenal for the combat. Therefore, the threat of acceleration and contagion of corruption in the context of EU enlargement in Western Balkans can be best blocked by focusing not on the candidates, but on the existing players in the single market.

- The primary anticorruption acts by the current EU countries should be oriented towards the business transactions of domestic firms penetrating into the new markets. In this respect, the building block is the OECD anti-corruption convention. The European power states Germany, United Kingdom, Netherlands, France, and Belgium should be fairly well equipped in its enforcement, not to mention the Nordic welfare states Denmark, Finland, and Sweden. Other 
countries that score above the EU average in terms of $C P I$, and $G E$ and $R L$ should also be capable to conduct the enforcement, especially if they are nudged to do so.

- Italy is in a special position, because it scores poorly both in terms of corruption and quality of governance, and because it is a notable intra-EU trader with close connections to the Western Balkans over the Adriatic sea. Thus, the EU must watch closely Italian firms and governance. The badly corrupted neighbors Bulgaria, Croatia, Greece, Hungary, and Romania are in special danger of acceleration and spreading of corruption thus deserving the same treatment. Since a majority of the present EU states score below the current average in terms of $C P I$ or $G E$ or $R L$, there is a considerable need for persistent centralized scrutiny by the EU.

- To sum up, corruption and bad governance are intertwined, and rooting out corruption cannot happen without remedying governance. Therefore, proper anti-corruption policy should consist of primary measures, that is strict enforcement of the OECD anticorruption convention, and secondary measures, that is long-term building of the European Integrity Community. The virtue of the primary shield against contagion of corruption is twofold. First, it gives time for the secondary measure, the replacement of corrupted informal governance by legitimate formal governance in the new as well as in some of the old EU partners. Second, the unbreakable shield erects inherent motives for gradual reforms by the problematic states themselves.

\section{Appendix}

The current EU28 countries with their CPI, GE, and RL scores in 2015

\begin{tabular}{l|c|c|c}
\hline \multicolumn{1}{c|}{ Country } & CPI 2015 & GE 2015 & RL 2015 \\
\hline Denmark & 91 & 1.85 & 2.04 \\
\hline Finland & 90 & 1.82 & 2.07 \\
\hline Sweden & 89 & 1.81 & 2.04 \\
\hline Netherlands & 87 & 1.84 & 1.93 \\
\hline Germany & 83 & 1.74 & 1.43 \\
\hline Luxemburg & 81 & 1.72 & 1.86 \\
\hline United Kingdom & 81 & 1.74 & 1.81 \\
\hline Belgium & 77 & 1.44 & 1.42 \\
\hline Austria & 76 & 1.47 & 1.85 \\
\hline Ireland & 75 & 1.54 & 1.79 \\
\hline Estonia & 70 & 1.09 & 1.33 \\
\hline France & 70 & 1.44 & 1.43 \\
\hline Portugal & 63 & 1.23 & 1.14 \\
\hline Poland & 62 & 0.80 & 0.80 \\
\hline Cyprus & 61 & 1.04 & 1.01 \\
\hline Lithuania & 61 & 1.20 & 0.98 \\
\hline
\end{tabular}




\begin{tabular}{|c|c|c|c|}
\hline Country & CPI 2015 & GE 2015 & RL 2015 \\
\hline Slovenia & 60 & 0.97 & 0.95 \\
\hline Spain & 58 & 1.18 & 0.90 \\
\hline Czech Republic & 56 & 1.05 & 1.12 \\
\hline Malta & 56 & 0.85 & 1.12 \\
\hline Latvia & 55 & 1.10 & 0.79 \\
\hline Croatia & 51 & 0.51 & 0.20 \\
\hline Hungary & 51 & 0.49 & 0.40 \\
\hline Slovakia & 51 & 0.84 & 0.48 \\
\hline Greece & 46 & 0.25 & 0.24 \\
\hline Romania & 46 & -0.04 & 0.15 \\
\hline Italy & 44 & 0.45 & 0.25 \\
\hline Bulgaria & 41 & 0.22 & -0.12 \\
\hline Average & 65.43 & 1.13 & 1.12 \\
\hline
\end{tabular}

Source: The data from http://ec.europa.eu/eurostat/web/international-trade-in-goods/statistics-illustrated

Checchi F. (2017) Corruption is Holding ASEAN Back. The Diplomat (Jan 31.2017). Retrieved June 2018 from https://thediplomat.com/2017/01/corruption-is-holding-asean-back

European Parliament Think Tank. (2016). The Western Balkans and the EU: Enlargement and challenges. Retrieved October 12, 2016, from http://www. europarl.europa.eu/thinktank/en/document.html?reference=EPRS_BRI\%282016\%29589791

Eurostat (2015). Retrieved October 18, 2016, from http://ec.europa.eu/eurostat/web/international-trade-in-goods/statistics-illustrated

Fisman R. \& Golden M. A. (2017). Corruption: What Everyone Needs to Know. New York: Oxford University Press.

Kauffman D. \& Wei S.J. (2000). Does grease money speed up the wheels of commerce? International Monetary Fund Policy Working Paper (No. 00/64).

Kauffman D, Kraay A. \& Mastruzzi M. (2010). The Worldwide Governance Indicators: Methodology and Analytical Issues. World Bank Policy Research Working Paper (No. 5430).

Kéïta K. \& Laurila H. (2017). Governance and corruption - sand or grease in the wheels? (Unpublished manuscript).
Kurer 0, (1993). Clientelism, corruption, and the allocation of resources. Public Choice, 77, 259-273. https://doi.org/10.1007/BF01047869

Mankiw, N. Gregory and D. N. Weil (1992). A contribution to the empirics of economic growth. Quarterly Journal of Economics 107, 407-437. https:// doi.org/10.2307/2118477

Mauro P. (1995). Corruption and growth. Quarterly Journal of Economics, Vol. 110 (3), 681-712. ttps://doi.org/10.2307/2946696

Méndez F. \& F. Sepúlveda (2006). Corruption, growth, and political regimes: cross country evidence. European Journal of Political Economy, 22. https://doi.org/10.1016/j.ejpoleco.2005.04.005

Méon P-G. \& K. Sekkat (2005). Does corruption sand or grease the wheels of growth? Public Choice, 122. https://doi.org/10.1007/s11127-005-3988-0

Méon P-G. \& L. Weill (2008). Is corruption an efficient grease? BOFIT Discussion Papers (No. 20).

Mo P. (2001). Corruption and economic growth. Journal of Comparative Economics, 29, 66-79. https://doi.org/10.1006/jcec.2000.1703

Myrdal G. (1968). Asian Drama. New York: Random House. 
OECD (1997). Convention on Combating Bribery of Foreign Public Officials in International Business Transactions. Retrieved June 2018 from http:// www.oecd.org/daf/anti-bribery/oecdantibriberyconvention.htm

Parsons T. (1970). The Social System. London: Routledge \& Kegan Paul Ltd.

Popov, S. V (2015). Decentralized bribery and market participation. The Scandinavian Journal of Economics, 117 (1): 108-125. https://doi.org/10.1111/ sjoe. 12081

Rodrik D. (2011). The Globalization Paradox: Why Global Markets, States, and Democracy Can't Coexist? Oxford: Oxford University Press.

Transparency International (2015). Asean Integrity Community - a vision for transparent and accountable integration.
Transparency International (2016a). Corruption Perceptions Index. Retrieved October 14, 2016, from http://www.transparency.org/cpi2015\#results-table

Transparency International (2016b). Definition of corruption. Retrieved October 14, 2016, from https://www.transparency.org/what-is-corruption/\#define

Ugur M. (2014). Corruption's Direct Effects on Per-Capita Income Growth: A Meta-Analysis. Journal of Economic Surveys, 28(3), 472-490. https:// doi.org/10.1111/joes. 12035

Wold Bank (2016). Worldwide Governance Indicators. Retrieved October 18, 2016, from http:// databank.worldbank.org/data/reports.aspx?Report_Name=WGI-Table\&Id =ceea $4 \mathrm{~d} 8 \mathrm{~b}$

\section{About the author \\ LAURILA HANNU \\ Dr./Professor \\ University of Tampere, Faculty of Management}

\section{Fields of research interests}

Public economics; urban and regional economics;

finance

\section{Address}

Fl-33014 University of Tampere, Finland

Tel. +358 503185998

E-mail: hannu.laurila@uta.fi 